\title{
The Proinflammatory Potential of Nitrogen Dioxide and Its Influence on the House Dust Mite Allergen Der p 1
}

\author{
Christian Koehler ${ }^{\mathrm{a}, \mathrm{b}}$ Michael Paulus ${ }^{\mathrm{a}}$ Christian Ginzkey $^{\mathrm{c}}$ \\ Stephan Hackenberg ${ }^{a}$ Agmal Scherzad ${ }^{a}$ Pascal Ickrath ${ }^{a}$ \\ Rudolf Hagen $^{\text {a }}$ Norbert Kleinsasser ${ }^{\mathrm{a}}$
}

\begin{abstract}
a Department of Oto-Rhino-Laryngology, Plastic, Aesthetic and Reconstructive Head and Neck Surgery, University Hospital of Würzburg, Würzburg, ${ }^{b}$ DIAKO Hospital Bremen, Bremen, and 'Department of Oto-Rhino-Laryngology, Head and Neck Surgery, Otto Koerner Rostock University Medical Center, Rostock, Germany
\end{abstract}

\section{Key Words}

Nitrogen dioxide - Der $\mathrm{p} 1 \cdot$ House dust mite allergen .

Interleukin-6 Interleukin-8

\begin{abstract}
Asthma and allergies are both major global health problems with an increasing prevalence, and environmental data implicate an influence of air pollutants on their development. The present study focuses on the influence of nitrogen dioxide $\left(\mathrm{NO}_{2}\right)$ and the major allergen of the house dust mite Der p 1 on human nasal epithelial cells of nonallergic patients in vitro. Nasal epithelial mucosa samples of 11 donors were harvested during nasal air passage surgery and cultured as an air-liquid interface. Exposure to $0.1,1$ and $10 \mathrm{ppm} \mathrm{NO}_{2}$ or synthetic air as a control was performed for $1 \mathrm{~h}$. Subsequent$l y$, the cells were exposed to Der $p 1$ for $24 \mathrm{~h}$. The release of interleukin (IL)- 6 and IL-8 was measured by ELISA, and the production of IL- 6 mRNA and IL-8 mRNA was measured by RT-PCR. $\mathrm{NO}_{2}$ exposure resulted in a concentration-dependent release of IL-6, but not IL-8 release. The coexposure of 0.1 ppm NO $\mathrm{N}_{2}$ and Der p 1, or 1 ppm NO $\mathrm{N}_{2}$ and Der $\mathrm{p} 1$ significantly increased both IL-6 and IL-8 release. Exposure to $\mathrm{NO}_{2}$, Der $\mathrm{p} 1$, or their combination, did not significantly influence the production of IL-6 or IL-8 mRNA. In conclusion, $\mathrm{NO}_{2}$ in-
\end{abstract}

\section{KARGER}

๑ 2016 S. Karger AG, Basel

E-Mail karger@karger.com

www.karger.com/iaa creases the release of inflammatory cytokines in human nasal epithelial cells, especially in coexposure with Der $p 1$, as a mechanism of allergotoxicology.

(c) 2016 S. Karger AG, Basel

\section{Introduction}

Nitrogen oxides are mainly generated by combustion processes indoors from domestic gas cookers, and outdoors by the combustion of fossil fuels. Nitrogen monoxide (NO) rapidly transforms into nitrogen dioxide $\left(\mathrm{NO}_{2}\right)$ by reaction with ozone. Therefore, $\mathrm{NO}_{2}$ concentrations are elevated in urban and industrial areas. Thus, it is of major concern that the particulate oxidation catalysts of modern engines increase the emission of nitrogen oxides [1]. Hence, this paper focuses on possible health hazards of $\mathrm{NO}_{2}$ on humans.

In this context, the toxic effects of $\mathrm{NO}_{2}$ have been widely discussed [2-4]. Genotoxic effects of low $\mathrm{NO}_{2}$ concentrations on nasal epithelial cells were previously analyzed by our group [5-7]. To summarize that work, the genotoxicity of $\mathrm{NO}_{2}$ could be demonstrated at a concentration as low as $0.01 \mathrm{ppm} \mathrm{NO} \mathrm{NO}_{2}$ indicated by DNA fragmentation in the Comet assay and micronucleus for- 
mation. A threshold of $\mathrm{NO}_{2}$ genotoxicity could not be defined. Besides the genotoxic potential, $\mathrm{NO}_{2}$ is also hazardous to humans due to its inflammatory effect and increase in airway responsiveness $[8,9]$. This leads to bronchial hyperreactivity and a decrease in lung function. Experimental settings demonstrated that exposure to 2-4 ppm $\mathrm{NO}_{2}$ in healthy test individuals did not change lung function [10], while concentrations of $0.25 \mathrm{ppm} \mathrm{NO}_{2}$ in patients with asthma or chronic obstructive pulmonary disease jeopardized lung function $[11,12]$. Tunnicliffe et al. [13] described a 'no-effect concentration' of $0.1 \mathrm{ppm}$ $\mathrm{NO}_{2}$, and Berglund et al. [14] suggested a possible threshold at this concentration. On the basis of these experimental studies, the WHO recommended a year-limit value of $0.02 \mathrm{ppm} \mathrm{NO}_{2}$ and a 1-hour-limit value of $0.1 \mathrm{ppm}$ $\mathrm{NO}_{2}[5,16]$.

Regarding the nasal epithelium, the prevalence of allergic rhinitis has increased in recent years [17]. Allergic rhinitis is a common global condition affecting 10-20\% of the adult population [18, 19]. Zhang and Zhang [17] correlated the increase in allergic rhinitis with the increase in industrialization and air pollution over the last 2 decades in China. Moreover, increased ambient $\mathrm{NO}_{2}$ has been consistently associated with an increased prevalence of allergic sensitization [20]. The mechanisms may involve an increase in airway responsiveness to allergens and allergenicity, as well as the increased bioavailability of airborne allergens from air pollution [21]. However, a significant association between long-term exposure to particulate matter (PM10) and $\mathrm{NO}_{2}$ with the prevalence of either asthma or wheezing was not observed [22]. Still, the interactions and additive effects of $\mathrm{NO}_{2}$ and allergens are not yet fully understood. Regarding allergens, the house dust mite is a typical indoor aeroallergen, and more than $60 \%$ of children that are sensitized to house dust mites have asthma, eczema, or rhinitis. House dust mites are an independent risk factor for the development of allergic respiratory diseases [23]. Der $p 1$ is one of the most allergenic major proteins of the house dust mite, and in 2010 Shi et al. [24] demonstrated the induction of interleukin (IL)- 6 and IL- 8 by Der $p 1$ in cultured human nasal epithelial cells and its association with the PAR/PI3K/ NFKB signaling pathway. Other authors could also show an increase in the IL- 6 and IL-8 production of airway cells by Der $\mathrm{p} 1$, which was induced by the cysteine protease activity of Der $\mathrm{p} 1$ [25-27].

How does $\mathrm{NO}_{2}$ influence cellular reactions to allergens? The present study focuses on exposure of the human nasal epithelium, representing the first target of the upper aerodigestive tract, to $\mathrm{NO}_{2}$, reflecting realistic ur- ban concentrations, and coexposure to Der $\mathrm{p} 1$. We hypothesized that $\mathrm{NO}_{2}$ exposure would enhance the production of IL- 6 and IL-8 induced by Der $\mathrm{p} 1$, and thereby boost the allergenic potential of Der $\mathrm{p} 1$.

\section{Materials and Methods}

Isolation and Cultivation of Human Nasal Epithelial Cells

Nasal epithelial cells were obtained from 11 patients who underwent sinus surgery or turbinoplasty, and the samples were delivered to our laboratory in $5 \mathrm{ml}$ of saline solution within $5 \mathrm{~min}$. Nasal polyps and the nasal epithelium from patients with allergies or other chronic epithelial diseases were excluded. Donors gave written informed consent for participation and the study was approved by the Ethics Board of the Medical Faculty of the University of Würzburg according to the approval notification dated February 2006, No. 16/06.

Isolation and cultivation of the cells were carried out as previously described [5]. In brief, after isolation the cells of each donor were cultured on 27 porous membrane inserts (Corning ${ }^{\circledR}$ Transwell polycarbonate membrane inserts, $0.4 \mu \mathrm{m} ; 12 \mathrm{~mm}$ diameter; Corning Inc., New York, N.Y., USA), covered with $150 \mu \mathrm{l}$ of collagen I ( 66 ng/ml; Sigma-Aldrich, St. Louis, Mo., USA). After reaching $70-80 \%$ confluence on day 7 , the medium apical to the membrane was removed, and nutrition was provided to the cells by adding $1.3 \mathrm{ml}$ of Airway Epithelial Cell Medium (PromoCell, Heidelberg, Germany) per insert under the membrane. At this point, the cultures reached an air-liquid interface condition, which was maintained from day 7 to 14 to stabilize the culture conditions. Therefore, all the cells were in passage 1 . Subsequently, the membranes with the cells were used for $\mathrm{NO}_{2}$ and control exposure.

\section{Gas Mixtures}

For $\mathrm{NO}_{2}$ exposure, a gas mixture construction was developed on the basis of mass-flow controllers (Bronkhorst High-Tech B.V., Ruurlo, The Netherlands), thus achieving a defined and controlled concentration of $\mathrm{NO}_{2}$ by diluting $\mathrm{NO}_{2}$ with synthetic air [5]. The mixture of $0.1 \mathrm{ppm} \mathrm{NO} \mathrm{N}_{2}$ was made by mixing $10 \mathrm{ml} / \mathrm{min}$ of $10 \mathrm{ppm}$ $\mathrm{NO}_{2}$ with $990 \mathrm{ml} / \mathrm{min}$ of synthetic air (Linde Gas, Pullach, Germany) to achieve $1,000 \mathrm{ml} / \mathrm{min}$ of $0.1 \mathrm{ppm} \mathrm{NO} \mathrm{N}_{2}$. The other concentrations ( $1 \mathrm{ppm} \mathrm{NO}$ and 10 ppm $\mathrm{NO}_{2}$ ) were mixed similarly to achieve a $1,000 \mathrm{ml} / \mathrm{min}$ gas mixture. After the dilution process, the concentration of the dilution was analyzed by an inline $\mathrm{NO}_{2}$ analyzer during the entire exposure duration (Ansyco $\mathrm{GmbH}$, Karlsruhe, Germany), verifying that the gas dilution was stable during all experiments.

\section{Exposure}

Just before exposure, the Transwell membranes with the nasal epithelial cells were checked microscopically. The cell surfaces were then washed twice with sterile PBS, and the supernatant was removed under sterile conditions. To expose the cells, the Transwell membranes were transferred into a Vitrocell ${ }^{\circledR}$ exposure chamber (Vitrocell Systems GmbH, Waldkirch, Germany). For exposure, the gas dilution was drawn over the cell layer by vacuum without further humidification. The material of the exposure chamber consisted of glass, stainless steel, and polytetrafluorethylene to avoid absorption effects. The exposure chamber of each 
Fig. 1. Experimental setup. The various combinations of $\mathrm{NO}_{2}$ and Der $\mathrm{p} 1$ exposure are shown.

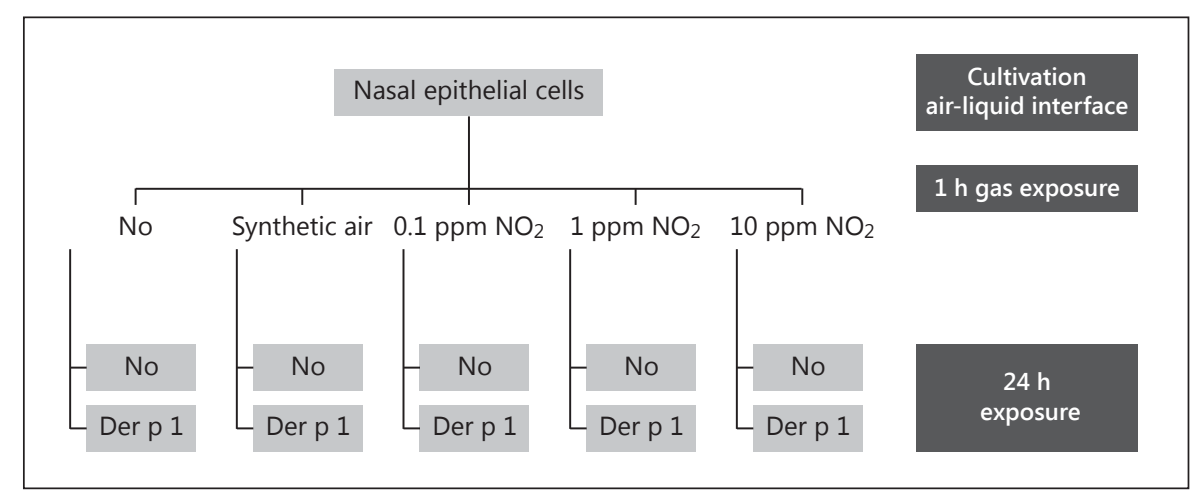

membrane had a volume of $2.5 \mathrm{ml}$. The flow rate of the vacuum was adjusted via mass-flow controllers at the gas outlets to $5 \mathrm{ml} /$ min; therefore, the volume change was $120 \times / h$.

The membranes were exposed to either $0.1 \mathrm{ppm} \mathrm{NO} 2,1 \mathrm{ppm}$ $\mathrm{NO}_{2}, 10$ ppm $\mathrm{NO}_{2}$ (Linde Gas Germany), or synthetic air free of hydrocarbons (Linde Gas Germany) for $1 \mathrm{~h}$. For each experiment, 1 membrane was used as a negative control and was not exposed.

After gas exposure, the samples were exposed to Der $\mathrm{p} 1$ for $24 \mathrm{~h}$. Therefore, 10 samples for the experimental setup were required (fig. 1). To expose the cells to Der p 1, LoTox Natural Der p 1 (Indoor Biotechnologies, Charlottesville, Va., USA) was used with endotoxins $\leq 0.03 \mathrm{EU} / \mu \mathrm{g}$. Der $\mathrm{p} 1$ was prepared according to the manufacturer's instructions. Der $\mathrm{p} 1$ was dissolved in PBS at a concentration of $10 \mu \mathrm{g} / \mathrm{ml}$. Sterile-filtered L-cysteine at a concentration of $5 \mathrm{mmol} / \mathrm{l}$ in PBS was added. The solution was incubated for $15 \mathrm{~min}$ at $37^{\circ} \mathrm{C}$ to oxidize the thiol group of Der $\mathrm{p} 1$. Thereby, the cysteine protease activity of Der p 1 was regained, which had been previously lost by the production process of Der $\mathrm{p} 1$. Der $\mathrm{p} 1$ was added to the basolateral medium of the wells at a concentration of $500 \mathrm{ng} / \mathrm{ml}$, and the samples were incubated for $24 \mathrm{~h}$ at $37^{\circ} \mathrm{C}$ in $5 \% \mathrm{CO}_{2}$. After exposure, the medium of the basolateral compartment was transferred to a $1.5-\mathrm{ml}$ vial and stored at $-20^{\circ} \mathrm{C}$ until further IL-6 and IL-8 ELISA analysis.

Thereafter, the cells were trypsinized from the membrane and centrifuged at $500 \mathrm{~g}$ for $5 \mathrm{~min}$. The cell pellets were resuspended in $500 \mu \mathrm{l}$ of PBS and centrifuged again. The cell pellets were lysed by adding $350 \mu \mathrm{l}$ of buffer RLT of the RNeasy mini kit (Qiagen, Venlo, The Netherlands). The lysates were stored at $-80^{\circ} \mathrm{C}$ until further analysis.

\section{IL-6 and IL-8 ELISA}

To determine the IL- 6 and IL- 8 concentrations, the cell medium of the samples was analyzed by human IL- 6 and IL- 8 ELISA kits (Diaclone SAS, Besançon, France). The experiments were carried out in duplicate. The ELISA plate was read at $450 \mathrm{~nm}$ (Titertek Multiskan PLUS; Labsystems, Helsinki, Finland). IL-6 and IL-8 concentrations $(\mathrm{pg} / \mathrm{ml})$ were determined by constructing a standard curve using recombinant IL- 6 and IL- 8 according to the manufacturer's instructions. Values lower than the detection limit were set as zero.

Total RNA Extraction, cDNA Synthesis, and RT-PCR

The effects of gas exposure and Der $\mathrm{p} 1$ exposure on mRNA expression of IL- 6 and IL- 8 were analyzed using RT-PCR. The fro- zen lysates were warmed to room temperature. Afterwards, RNA isolation was done using the RNeasy mini kit (Qiagen) according to the manufacturer's instructions. The remaining DNA was eliminated using an RNase-free DNase kit (Qiagen).

The concentration of extracted total RNA was analyzed photometrically at an extinction of $260 \mathrm{~nm}$, and the samples were diluted to equal RNA concentrations. The extracted total RNA was reverse transcribed to cDNA. The cDNA concentrations were measured using a photometer at an extinction of $320 \mathrm{~nm}$. The samples were normalized to an equal cDNA concentration of 200 $400 \mathrm{ng} / \mathrm{ml}$.

For the quantification of gene expression, the TaqMan Gene Expression Master Mix and the IL- 6 and IL- 8 primers were used (Life Technologies Corp., Carlsbad, Calif., USA; TaqMan Gene Expression Assay IL-6, assay ID Hs00985639_m1 and TaqMan Gene Expression Assay IL-8, assay ID Hs02758991_g1).

The amplifications for gene quantification were $50^{\circ} \mathrm{C}$ for $2 \mathrm{~min}$, $95^{\circ} \mathrm{C}$ for $10 \mathrm{~min}$, and 40 cycles at $95^{\circ} \mathrm{C}$ for $15 \mathrm{~s}$ and $60^{\circ} \mathrm{C}$ for $1 \mathrm{~min}$. The GAPDH gene was used as an endogenous control, and was quantified by TaqMan Gene Expression Assay GAPDH, assay ID Hs02758991_g1 (Life Technologies Corp.). The unexposed cells served as a negative control.

The relative mRNA expression was calculated by the $\Delta \Delta \mathrm{C}_{\mathrm{T}}$ method. $\Delta \mathrm{C}_{\mathrm{T}}$ of each sample was calculated by subtracting the $\mathrm{C}_{\mathrm{T}}$ of the target gene and the $\mathrm{C}_{\mathrm{T}}$ of GAPDH:

$$
\left.\Delta \mathrm{C}_{\mathrm{T}} \text { (target gene }\right)=\mathrm{C}_{\mathrm{T}}(\text { target gene })-\mathrm{C}_{\mathrm{T}}(\mathrm{GAPDH}) \text {. }
$$

Afterwards the $\Delta \Delta \mathrm{C}_{\mathrm{T}}$ (target gene) was calculated for each exposure:

$\Delta \Delta \mathrm{C}_{\mathrm{T}}$ (target gene $)=\Delta \mathrm{C}_{\mathrm{T}}$ (target gene $)-\Delta \mathrm{C}_{\mathrm{T}}$ (target gene of negative control).

The relative gene expression of IL- 6 and IL- 8 mRNA was determined as follows:

Relative gene 3expression $=2^{-\Delta \Delta \mathrm{C}_{\mathrm{T}} \text { (target gene) }}$.

\section{Statistical Analysis}

The statistical analyses were done using GraphPad Prism 5.0 (GraphPad Software, La Jolla, Calif., USA). We used the nonparametric Friedman test for related samples at different gas exposure concentrations. To compare equal exposure concentrations with or without Der $\mathrm{p} 1$, the nonparametric Wilcoxon test for 2 related samples was used. For statistical analysis of the ELISA, the concen- 


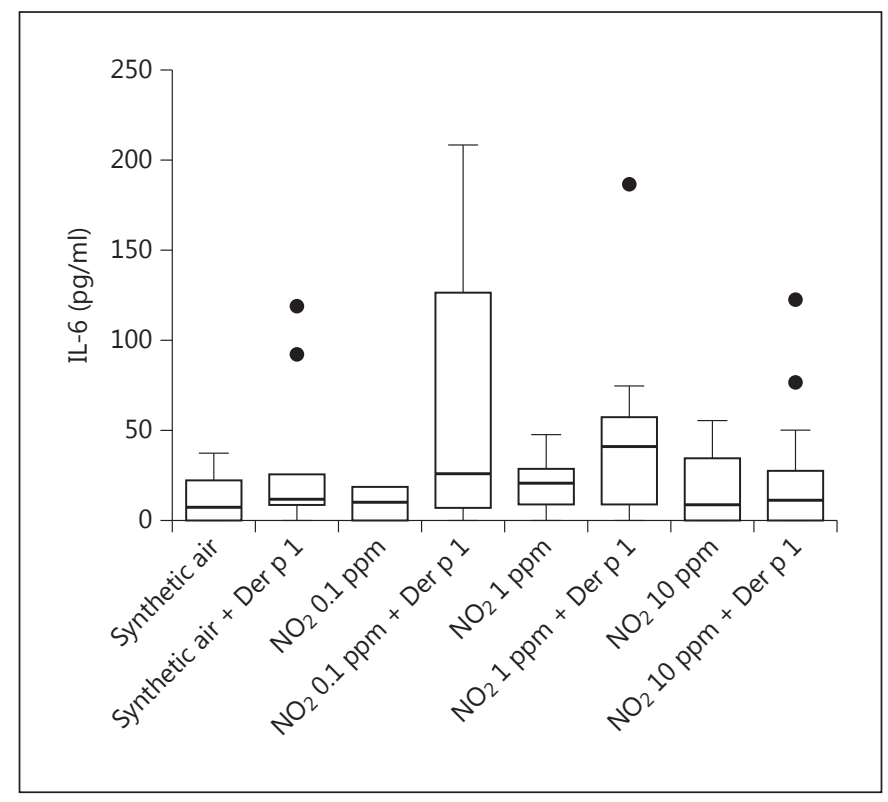

Fig. 2. IL-6 ELISA. The boxplots represent IL-6 levels after exposure to synthetic air or $\mathrm{NO}_{2}$ at increasing concentrations alone and in coexposure with Der p 1. For the definition of boxplots see Statistical Analysis. Coexposure of Der p 1 with 0.1 or 1 ppm $\mathrm{NO}_{2}$ led to a significant IL-6 release.

trations of IL- 6 and IL- 8 (pg/ml) were compared. To determine the mRNA production of IL- 6 or IL-8, the relative gene expressions were compared.

Boxplots were used to chart the results. The box represents the area of $50 \%$ of all values, and is bordered by the upper and lower quartile. The median is represented by a line in the box, and divides the box into 2 parts with $50 \%$ of the values in each box. The whiskers of the boxes show values outside the boxes, and are limited to a length of 1.5 interquartile distances according to the definition of John W. Tukey. Values outside the whiskers with more than 1.5 interquartile distances are indicated as outliers by a dot.

\section{Results}

\section{ELISA}

IL- 6 and IL- 8 production was analyzed by ELISA. Regarding exposures to elevated concentrations of $\mathrm{NO}_{2}$ alone, a concentration-dependent increase in IL- 6 ( $\mathrm{p}<$ 0.05 , Friedman test) could be measured, while IL- 8 was not influenced ( $\mathrm{p}>0.05$, Friedman test) by increasing concentrations of $\mathrm{NO}_{2}$. Regarding the effect of Der $\mathrm{p} 1$, the coexposure of Der $\mathrm{p} 1$ to 0.1 and $1 \mathrm{ppm} \mathrm{NO}$ resulted in a significant increase in IL-6 production, while Der $\mathrm{p} 1$ did not influence the IL- 6 production in the coexposures

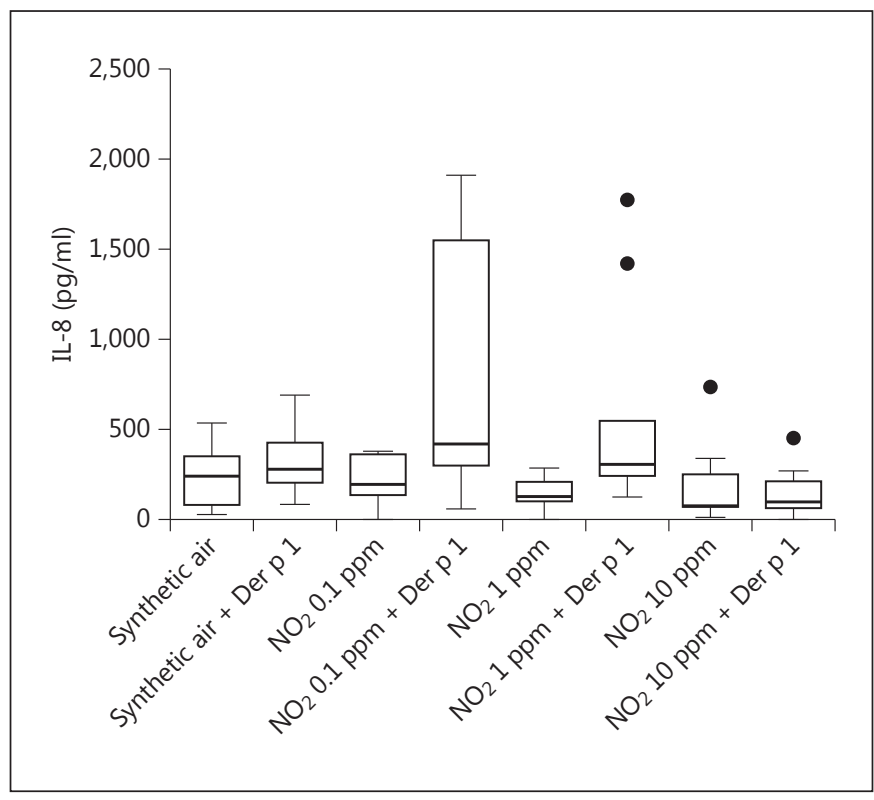

Fig. 3. IL-8 ELISA. The boxplots represent IL-8 levels after exposure to synthetic air or $\mathrm{NO}_{2}$ at increasing concentrations alone and in coexposure with Der $\mathrm{p}$ 1. For the definition of boxplots see Statistical Analysis. Coexposure of Der p 1 with 0.1 or 1 ppm $\mathrm{NO}_{2}$ led to a significant IL-8 release.

with synthetic air or $10 \mathrm{ppm} \mathrm{NO}_{2}$ (Wilcoxon test; fig. 2). The effect of Der $p 1$ on IL-8 production during coexposure with the different gas dilutions was similar to the IL-6 production, with a significant increase in IL- 8 by coexposure to Der p 1 with $0.1 \mathrm{ppm} \mathrm{NO}_{2}$ or $1 \mathrm{ppm} \mathrm{NO}_{2}$ (Wilcoxon test; fig. 3). The boxplots show that Der p 1 induces IL- 6 and IL-8 production mainly during coexposure with $0.1 \mathrm{ppm} \mathrm{NO}_{2}$. The ELISA data are presented in table 1.

\section{$R T-P C R$}

All data, including the relative gene expression of IL-6 and IL-8 mRNAs, are presented in table 2. For all 11 samples, elevating concentrations of $\mathrm{NO}_{2}$ did not influence IL-6 or IL- 8 mRNA expression ( $p>0.05$, Friedman test). The IL- 6 mRNA expression was even not influenced by the addition of Der $\mathrm{p} 1$ to different gas exposures ( $\mathrm{p}>$ 0.05 , Wilcoxon test; fig. 4). A significant increase in IL-8 mRNA expression could be observed at a coexposure of Der p 1 with 1 ppm $\mathrm{NO}_{2}$ only ( $\mathrm{p}<0.05$, Wilcoxon test). Any other combination of Der $\mathrm{p} 1$ exposure with additive gas exposures did not influence IL-8 mRNA expression (fig. 5). 
Table 1. IL-6 and IL-8 concentrations ( $\mathrm{pg} / \mathrm{ml}$ ) of the cell medium

\begin{tabular}{|c|c|c|c|c|c|c|c|c|}
\hline No. & Synthetic air & $\begin{array}{l}\text { Synthetic air + } \\
\text { Der p } 1\end{array}$ & $\mathrm{NO}_{2} 0.1 \mathrm{ppm}$ & $\begin{array}{l}\mathrm{NO}_{2} 0.1+ \\
\text { Der p } 1\end{array}$ & $\mathrm{NO}_{2} 1 \mathrm{ppm}$ & $\begin{array}{l}\mathrm{NO}_{2} 1+ \\
\text { Der p } 1\end{array}$ & $\mathrm{NO}_{2} 10 \mathrm{ppm}$ & $\begin{array}{l}\mathrm{NO}_{2} 10+ \\
\text { Der p } 1\end{array}$ \\
\hline \multicolumn{9}{|l|}{$I L-6$} \\
\hline 1 & 8.10 & 12.39 & 17.00 & 26.52 & 28.14 & 42.23 & 19.54 & 27.91 \\
\hline 2 & 0 & 9.08 & 0 & 23.77 & 20.94 & 35.98 & 0 & 21.21 \\
\hline 3 & 15.09 & 12.17 & 10.66 & 34.45 & 120.23 & 187.32 & 55.14 & 76.83 \\
\hline 4 & 35.07 & 9.88 & 12.78 & 31.17 & 20.86 & 38.02 & 8.12 & 6.38 \\
\hline 6 & 22.64 & 119.06 & 140.75 & 171.02 & 19.82 & 41.41 & 0 & 0 \\
\hline 7 & 0 & 8.88 & 0 & 126.57 & 47.97 & 44.33 & 16.59 & 11.63 \\
\hline 8 & 0 & 13.45 & 0 & 0 & 0 & 0 & 0 & 0 \\
\hline 9 & 0 & 0 & 6.60 & 0 & 9.46 & 0 & 8.90 & 9.32 \\
\hline 10 & 10.98 & 92.75 & 93.30 & 208.46 & 24.05 & 57.72 & 55.64 & 23.11 \\
\hline 11 & 37.68 & 25.73 & 18.88 & 7.24 & 28.93 & 9.58 & 34.56 & 123.30 \\
\hline \multicolumn{9}{|l|}{$I L-8$} \\
\hline 1 & 355.83 & 131.70 & 383.17 & $1,042.82$ & 103.97 & 251.55 & 71.91 & 92.07 \\
\hline 2 & 86.04 & 208.39 & 142.20 & $1,548.80$ & 263.81 & 375.33 & 137.04 & 272.37 \\
\hline 3 & 104.12 & 283.06 & 111.83 & 300.39 & 103.41 & 356.51 & 72.45 & 170.29 \\
\hline 4 & 537.26 & 86.62 & 199.59 & 324.67 & 288.42 & 549.40 & 81.51 & 0 \\
\hline 5 & 93.04 & 690.72 & 157.58 & 420.66 & 198.46 & 1776.48 & 252.54 & 65.79 \\
\hline 6 & 419.26 & 352.92 & 364.31 & 252.54 & 118.84 & 130.47 & 67.39 & 67.16 \\
\hline 7 & 29.70 & 208.84 & 0 & $1,911.93$ & 0 & 247.00 & 14.57 & 0 \\
\hline 8 & 241.24 & 329.12 & 272.50 & 673.86 & 130.46 & 309.21 & 78.20 & 100.37 \\
\hline 9 & 259.22 & 206.09 & 168.98 & 338.87 & 210.72 & 295.62 & 78.86 & 213.40 \\
\hline 10 & 78.59 & 682.54 & 944.87 & $1,777.01$ & 131.40 & $1,421.04$ & 737.23 & 189.35 \\
\hline
\end{tabular}

\section{Discussion}

The aim of the current study was to examine the influence of an environmental pollutant on the extent of cytokine release of upper airway epithelial cells to an allergen. Therefore, we focused on Der $\mathrm{p}$ 1, which is the most important allergen of the house dust mite, and $\mathrm{NO}_{2}$ as a reactive environmental pollutant.

Most studies to date have evaluated the hazardous potential of $\mathrm{NO}_{2}$ or Der $\mathrm{p} 1$ alone. Studies considering a synergistic effect of both a major allergen and a volatile reactive gas are rare. A recent study by Elshabrawy et al. [29] examined the impact of environmental and agricultural pollutants on the prevalence of allergic diseases. The authors demonstrated that subjects which are high- ly exposed to environmental and agricultural pollution are at a high risk for developing allergies. The current study was therefore unique by analyzing the effect of an environmental allergen on the effect of an allergen in vitro.

Existing studies on Der $\mathrm{p} 1$ have shown the induction of IL- 6 and IL-8 production in airway epithelial cells. The mechanism of IL- 6 and IL- 8 production is based on the cysteine protease activity of Der $\mathrm{p} 1$, which could be demonstrated in several studies [24-27]. Der $\mathrm{p} 1$ seems to induce the PAR/PI3K/NFKB signaling pathway, and thereby the induction of IL-6 and IL-8 [24, 25, 28]. Besides a Der $\mathrm{p} 1$ protease-dependent signaling pathway, Der $\mathrm{p} 1$ triggers a protease-independent signaling pathway in airway epithelial cells. IL-6 and IL-8 release results in an in- 
Table 2. Relative mRNA expression of IL- 6 and IL-8

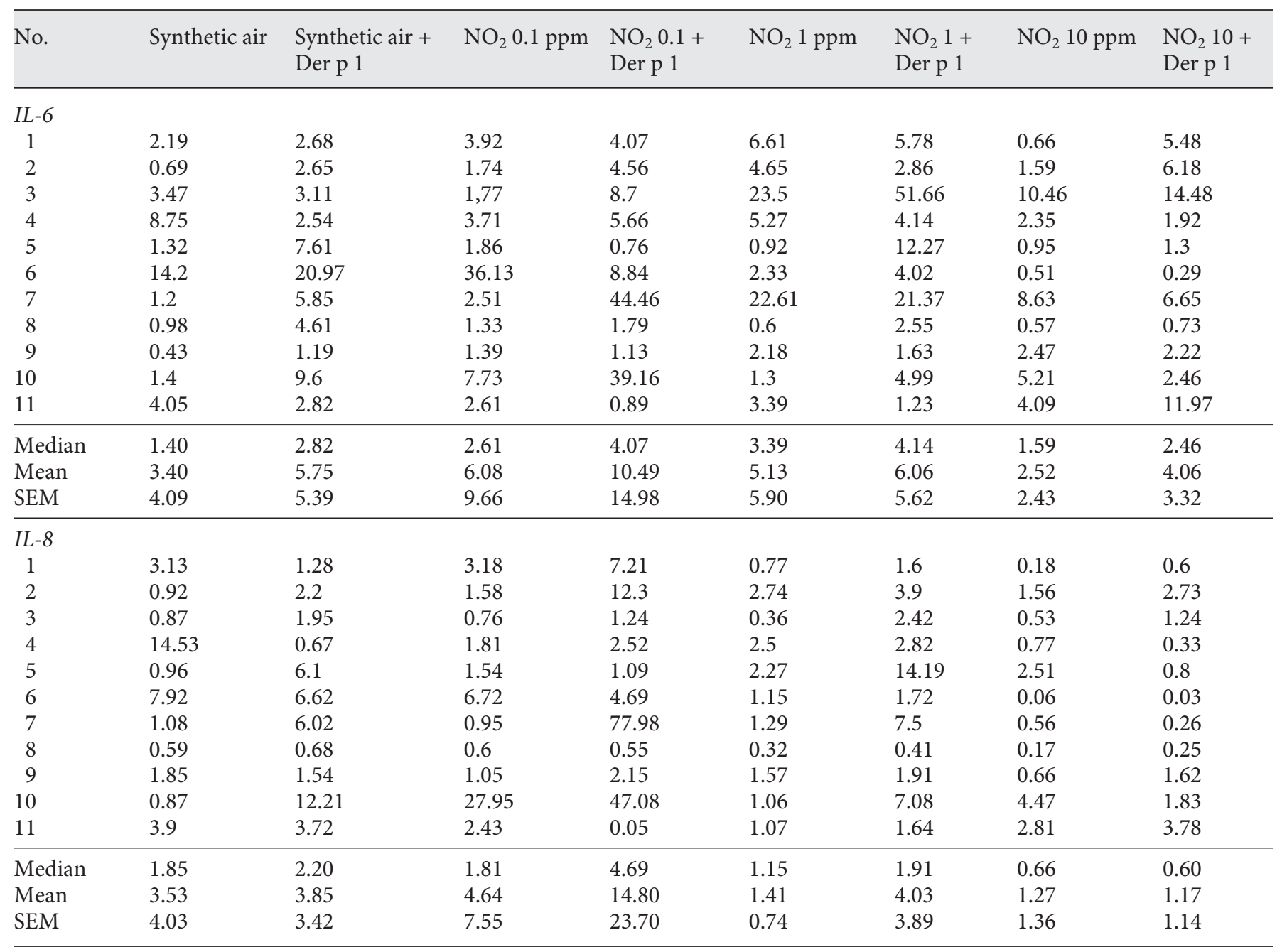

flammatory response, which may be the first step in airway inflammation.

$\mathrm{NO}_{2}$ itself also has an inflammatory effect in addition to toxic and genotoxic properties. Hence, in air pollution regulations, threshold values of $\mathrm{NO}_{2}$ have been implemented in several countries, following the recommendations of the WHO $[15,16]$. The WHO suggested an annual limit value of $40 \mu \mathrm{g} / \mathrm{m}^{3}$, which equals approximately $0.02 \mathrm{ppm} \mathrm{NO} \mathrm{N}_{2}$, and a 1 -hour maximum of $200 \mu \mathrm{g} / \mathrm{m}^{3}$, reflecting $0.1 \mathrm{ppm} \mathrm{NO} \mathrm{N}_{2}$. The WHO defined threshold values based, among other things, on the experiments by Tunnicliffe et al. [13] who described a no-effect concentration level of $0.1 \mathrm{ppm} \mathrm{NO}$. These recommendations are based on experimental studies dealing with $\mathrm{NO}_{2}$ alone. However, by assuming an additive or synergistic effect of air pollutants and allergens, a detailed analysis on the ex- posure of airway cells to volatile environmental pollution, such as $\mathrm{NO}_{2}$, and allergenic components, such as Der $\mathrm{p} 1$, is of great interest.

The presented data demonstrated the influence of elevated $\mathrm{NO}_{2}$ concentrations on IL- 6 discharge in the cell medium, as measured by ELISA. $\mathrm{NO}_{2}$ alone could not influence IL-8 discharge. The addition of Der p 1 (10 $\mu \mathrm{g} /$ $\mathrm{ml}$ ) to $\mathrm{NO}_{2}$ exposure resulted in an enormous increase in IL-6 and IL- 8 in the cell medium, especially at the 1-hourlimit value of $0.1 \mathrm{ppm} \mathrm{NO} \mathrm{N}_{2}$. The current study thus demonstrated a synergistic effect of allergenic compounds and airway pollution at a low concentration of $\mathrm{NO}_{2}$, reflecting realistic values for urban areas. It is of major concern that the nasal epithelial cells of nonallergic subjects reacted via an inflammatory response to the combination of $\mathrm{NO}_{2}$ and Der $\mathrm{p} 1$, which may be an initial step in aller-
32

Int Arch Allergy Immunol 2016;171:27-35 DOI: $10.1159 / 000450751$
Koehler/Paulus/Ginzkey/Hackenberg/

Scherzed/Ickrath/Hagen/Kleinsasser 


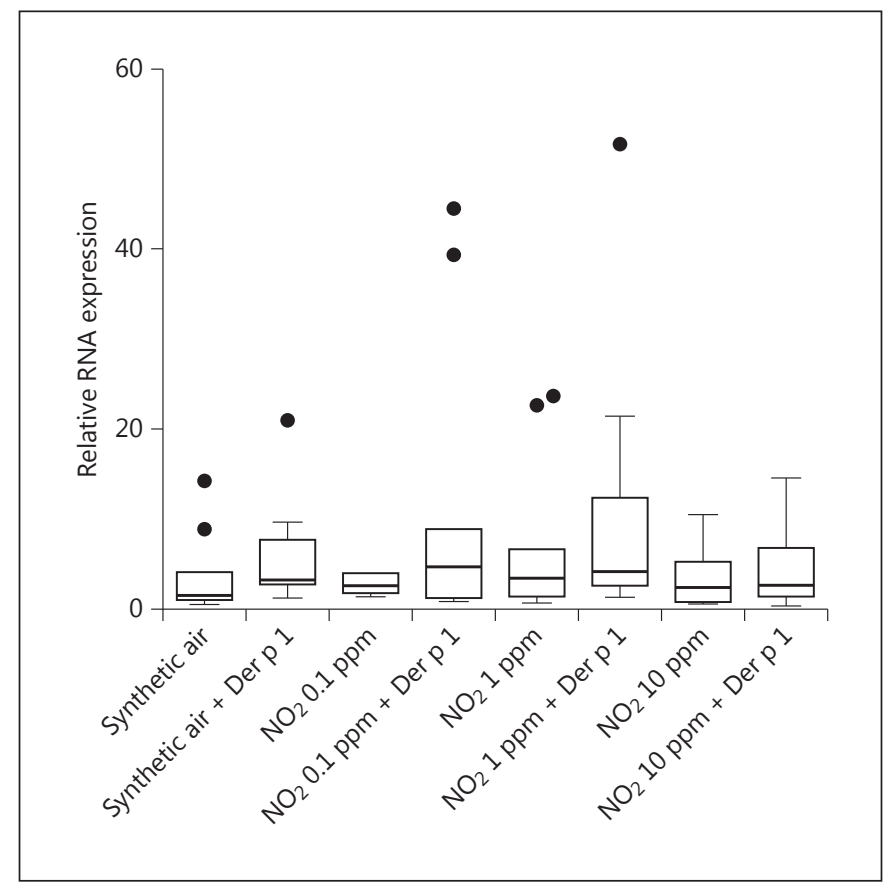

Fig. 4. IL-6 RT-PCR. The boxplots represent relative IL-6 mRNA expression after exposure to synthetic air or $\mathrm{NO}_{2}$ at increasing concentrations alone and during coexposure with Der $\mathrm{p} 1$. For the definition of boxplots see Statistical Analysis. Coexposure to Der p 1 did not influence IL-6 mRNA expression.

gen sensitization. These findings are in line with the environmental studies of Elshabrawy et al. [29], and to our knowledge this is the first in vitro study to analyze the impact of volatile air pollution on human cellular reactions to aeroallergens.

The increase in IL- 6 and IL- 8 in the cell medium was measurable at the 1-hour-limit value of $0.1 \mathrm{ppm} \mathrm{NO}_{2}$. We can speculate as to why this increase was not observable at higher $\mathrm{NO}_{2}$ concentrations. A possible explanation may be that the inflammation induced by higher $\mathrm{NO}_{2}$ concentrations occurred fairly rapidly, and thus IL- 6 and IL-8 in the cell medium were measured too late at $24 \mathrm{~h}$ after exposure. Higher concentrations of $\mathrm{NO}_{2}$ in combination with Der $\mathrm{p} 1$ probably induced cell damage that prevented higher levels of IL-6 and IL-8. Kauffman et al. [25] demonstrated cell shrinking and desquamation of A549 cells by elevated Der p 1 concentrations. Perhaps this process is already increased by higher $\mathrm{NO}_{2}$ concentrations in the presence of ambient Der $\mathrm{p} 1$ concentrations. In contrast, analysis by trypan blue did not show any significant changes in cell viability in our experiments. So far we do not have a conclusive explanation as

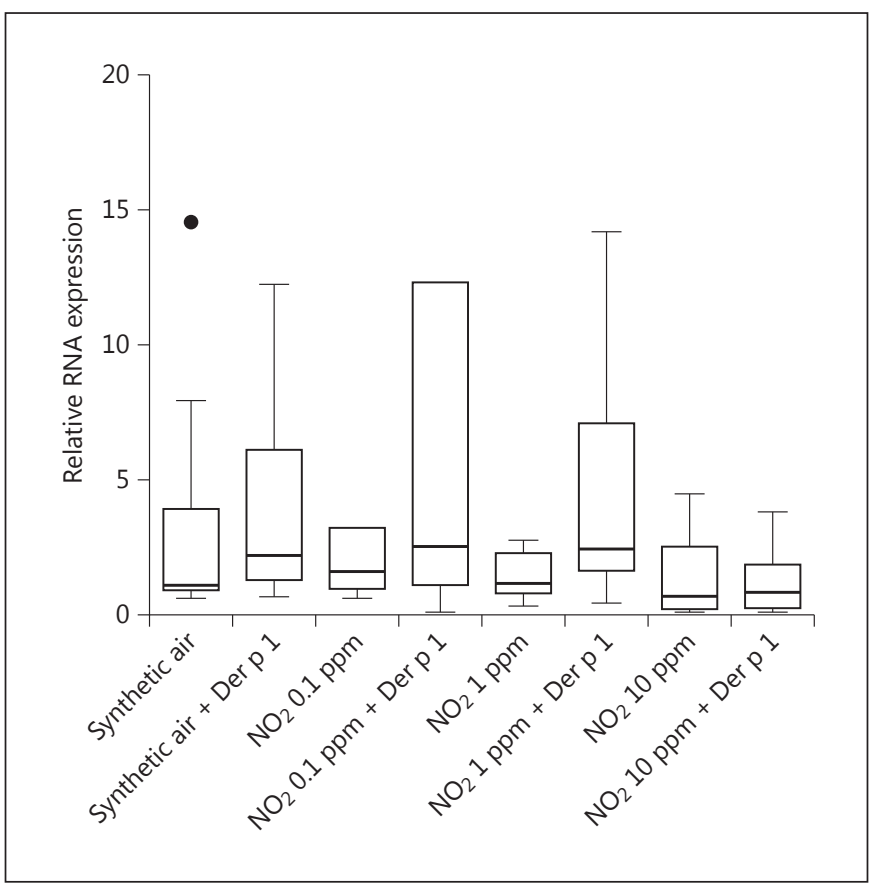

Fig. 5. IL-8 RT-PCR. The boxplots represent relative IL- 8 mRNA expression after exposure to synthetic air or $\mathrm{NO}_{2}$ at increasing concentrations alone and during coexposure with Der $\mathrm{p} 1$. For the definition of boxplots see Statistical Analysis. Coexposure to Der p 1 did not influence IL-8 mRNA expression.

to why the measured effects cannot be observed with higher $\mathrm{NO}_{2}$ exposure. Nevertheless, this effect could be seen in both analyses of IL- 6 and IL- 8 and should be reliable.

It was our aim to demonstrate the effect of Der $p 1$ and $\mathrm{NO}_{2}$ on protein and mRNA levels. In contrast to the ELISA results, the mRNA of IL- 6 and IL- 8 did not increase significantly. An explanation for this observation may be that $\mathrm{NO}_{2}$ and Der $\mathrm{p} 1$ induce a discharge of cellular IL-6 and IL-8 storage, but do not influence the intracellular accumulation of IL- 6 and IL-8. Another explanation may be that mRNA levels are elevated by extended exposure durations or in measurements made at a later time point. Our experimental setup with relatively short exposure durations did not influence the generation of intracellular IL- 6 and IL-8 but did increase the cellular release of these proteins. Therefore, the missing elevation of IL- 6 and IL- 8 mRNA levels is of speculation and an issue of further research.

Several studies have demonstrated epidemiological data that show a correlation between air pollution and the prevalence of asthma and allergies [8, 30-32]. However, 
the nasal mucosa air-liquid interface is not suitable as a test system for allergic diseases, since allergies are complex reactions involving epithelial cells, dendritic cells within the subepithelial tissue and perivascular/intranodular lymphocytes. However, allergic reactions are highly influenced by the coinflammatory conditions of the surrounding tissue. Proinflammatory cytokines like IL-6 or IL-8 support chemotaxis of lymphocytes or lymphocyte homing. Thus, we could demonstrate that a combined exposure of $\mathrm{NO}_{2}$ and allergens like Der $\mathrm{p} 1$ affects epithelial cells in terms of a proinflammatory response that supports the development of allergic reactions. We could assume that $\mathrm{NO}_{2}$ may intensify the reaction to Der $\mathrm{p} 1$ in an allergic subject and, moreover, may trigger an allergy in subjects that have allergic presuppositions, such as genetic conditions.

In addition, we could show that the air-liquid interface of nasal epithelial cells could be an adequate model for studying the underlying molecular mechanisms in vitro, and thus further research should focus on cellular reactions to air pollutants and potential allergens. In this context, it is important to focus on allergotoxicology, which means 'the investigation of effects of toxic substances upon the induction, elicitation, and maintenance of allergic reactions' [30]. The focus on allergotoxicology may give us a more specific insight into the mechanisms of al- lergens and an explanation for the increment of allergies worldwide. Having said that, further research should focus on more complex cellular systems, including the immune system.

Besides the mechanisms of allergotoxicology that concentrate on intracellular mechanisms, one should also take into account the fact that air pollutants may modify allergens to more reactive species. Ackaert et al. [33] showed that nitration of Bet $\mathrm{v} 1.0101$ results in a decreased production of Th1-priming cytokines and a shift towards a Th2 response in dendritic cells. Cuinica et al. [34] demonstrated an increase in the allergenicity of pollens that were exposed to air pollutants.

In the presented experimental setup, nasal epithelial cells were exposed to $\mathrm{NO}_{2}$ and Der $\mathrm{p} 1$ consecutively, and thus the effect of allergotoxicology may play a greater role than the effect of allergen modification by air pollutants. Nevertheless, both mechanisms have to be examined in more detail to elucidate the reason for the rise in asthma and allergies, which has a major social and economic impact across the globe.

\section{Disclosure Statement}

The authors declare that they have no conflicts of interest. This study was supported in part by the Rudolf-Bartling Foundation.

\section{References}

1 Feng X, Ge Y, Ma C, Tan J, Yu L, Li J, et al: Experimental study on the nitrogen dioxide and particulate matter emissions from diesel engine retrofitted with particulate oxidation catalyst. Sci Total Environ 2014;472:56-62.

2 Jerrett M, Finkelstein MM, Brook JR, Arain MA, Kanaroglou P, Stieb DM, et al: A cohort study of traffic-related air pollution and mortality in Toronto, Ontario, Canada. Environ Health Perspect 2009;117:772-777.

3 Jerrett M, Shankardass K, Berhane K, Gauderman WJ, Kunzli N, Avol E, et al: Traffic-related air pollution and asthma onset in children: a prospective cohort study with individual exposure measurement. Environ Health Perspect 2008;116:1433-1438.

4 Hansel NN, Breysse PN, McCormack MC, Matsui EC, Curtin-Brosnan J, Williams DL, et al: A longitudinal study of indoor nitrogen dioxide levels and respiratory symptoms in inner-city children with asthma. Environ Health Perspect 2008;116:1428-1432.
5 Koehler C, Ginzkey C, Friehs G, Hackenberg S, Froelich K, Scherzed A, et al: Aspects of nitrogen dioxide toxicity in environmental urban concentrations in human nasal epithelium. Toxicol Appl Pharmacol 2010;245:219-225.

6 Koehler C, Ginzkey C, Friehs G, Hackenberg S, Froelich K, Scherzed A, et al: Ex vivo toxicity of nitrogen dioxide in human nasal epithelium at the WHO defined 1-h limit value. Toxicol Lett 2011;207:89-95.

7 Koehler C, Thielen S, Ginzkey C, Hackenberg S, Scherzed A, Burghartz M, et al: Nitrogen dioxide is genotoxic in urban concentrations. Inhal Toxicol 2013;25:341-347.

8 Guarnieri M, Balmes JR: Outdoor air pollution and asthma. Lancet 2014;383:1581-1592.

9 Matsui EC: Environmental exposures and asthma morbidity in children living in urban neighborhoods. Allergy 2014;69:553-558.

10 Blomberg A, Krishna MT, Helleday R, Soderberg M, Ledin MC, Kelly FJ, et al: Persistent airway inflammation but accommodated antioxidant and lung function responses after repeated daily exposure to nitrogen dioxide. Am J Respir Crit Care Med 1999;159:536543.
11 Szabo C, Ohshima H: DNA damage induced by peroxynitrite: subsequent biological effects. Nitric Oxide 1997;1:373-385.

12 Strand V, Salomonsson P, Lundahl J, Bylin G: Immediate and delayed effects of nitrogen dioxide exposure at an ambient level on bronchial responsiveness to histamine in subjects with asthma. Eur Respir J 1996;9:733-740.

13 Tunnicliffe WS, Burge PS, Ayres JG: Effect of domestic concentrations of nitrogen dioxide on airway responses to inhaled allergen in asthmatic patients. Lancet 1994;344:17331736.

14 Berglund M: Health risk evaluation of nitrogen oxides: exposure. Scand J Work Environ Health 1993;19(suppl 2):14-20.

15 WHO: Air Quality Guidelines, ed 2. Copenhagen, WHO Regional Publications, 2000, p 91.

16 WHO: Air Quality Guidelines: Global Update 2005. Copenhagen, WHO Regional Publications, 2005 .

17 Zhang Y, Zhang L: Prevalence of allergic rhinitis in China. Allergy Asthma Immunol Res 2014;6:105-113.

Koehler/Paulus/Ginzkey/Hackenberg/ Scherzed/Ickrath/Hagen/Kleinsasser 
18 Bousquet J, Schunemann HJ, Samolinski B, Demoly P, Baena-Cagnani CE, Bachert C, et al: Allergic rhinitis and its impact on asthma (ARIA): achievements in 10 years and future needs. J Allergy Clin Immunol 2012;130: 1049-1062.

19 Brozek JL, Bousquet J, Baena-Cagnani CE, Bonini S, Canonica GW, Casale TB, et al: Allergic rhinitis and its impact on asthma (ARIA) guidelines: 2010 revision. J Allergy Clin Immunol 2010;126:466-476.

20 Weir CH, Yeatts KB, Sarnat JA, Vizuete W, Salo PM, Jaramillo R, et al: Nitrogen dioxide and allergic sensitization in the 2005-2006 National Health and Nutrition Examination Survey. Respir Med 2013;107:1763-1772.

21 Mosges R, Klimek L: Today's allergic rhinitis patients are different: new factors that may play a role. Allergy 2007;62:969-975.

22 Molter A, Agius R, de Vocht F, Lindley S, Gerrard W, Custovic A, et al: Effects of long-term exposure to $\mathrm{PM}_{10}$ and $\mathrm{NO}_{2}$ on asthma and wheeze in a prospective birth cohort. J Epidemiol Community Health 2014;68:21-28.

23 Huss K, Adkinson NF Jr, Eggleston PA, Dawson C, Van Natta ML, Hamilton RG: House dust mite and cockroach exposure are strong risk factors for positive allergy skin test responses in the Childhood Asthma Management Program. J Allergy Clin Immunol 2001; 107:48-54.
24 Shi J, Luo Q, Chen F, Chen D, Xu G, Li H: Induction of IL- 6 and IL- 8 by house dust mite allergen Der $\mathrm{p} 1$ in cultured human nasal epithelial cells is associated with PAR/PI3K/ NFKB signaling. ORL J Otorhinolaryngol Relat Spec 2010;72:256-265.

25 Kauffman HF, Tamm M, Timmerman JA, Borger P: House dust mite major allergens Der $\mathrm{p} 1$ and Der $\mathrm{p} 5$ activate human airwayderived epithelial cells by protease-dependent and protease-independent mechanisms. Clin Mol Allergy 2006;4:5.

26 King C, Brennan S, Thompson PJ, Stewart GA: Dust mite proteolytic allergens induce cytokine release from cultured airway epithelium. J Immunol 1998;161:3645-3651.

27 Tomee JF, van Weissenbruch R, de Monchy JG, Kauffman HF: Interactions between inhalant allergen extracts and airway epithelial cells: effect on cytokine production and cell detachment. J Allergy Clin Immunol 1998; 102:75-85.

28 Shin SH, Ye MK: The effect of nano-silver on the activation of nasal polyp epithelial cells by Alternaria, Der p 1 and staphylococcal enterotoxin B. Int Immunopharmacol 2011;11: 1691-1696.
29 Elshabrawy WO, Ismail HA, Hassanein KM: The impact of environmental and agricultural pollutants on the prevalence of allergic diseases in people from Qassim, KSA. Int Health Sci (Qassim) 2014;8:21-31.

30 Behrendt H, Alessandrini F, Buters J, Kramer U, Koren H, Ring J: Environmental pollution and allergy: historical aspects. Chem Immunol Allergy 2014;100:268-277.

31 Konishi S, Ng CF, Stickley A, Nishihata S, Shinsugi C, Ueda K, et al: Particulate matter modifies the association between airborne pollen and daily medical consultations for pollinosis in Tokyo. Sci Total Environ 2014; 499C:125-132.

32 Rutkowski K, Sowa P, Rutkowska-Talipska J, Sulkowski S, Rutkowski R: Allergic diseases: the price of civilisational progress. Postepy Dermatol Alergol 2014;31:77-83.

33 Ackaert C, Kofler S, Horejs-Hoeck J, Zulehner N, Asam C, von Grafenstein S, et al: The impact of nitration on the structure and immunogenicity of the major birch pollen allergen Betv 1.0101. PLoS One 2014;9:e104520.

34 Cuinica LG, Cruz A, Abreu I, da Silva JC: Effects of atmospheric pollutants $(\mathrm{CO}, \mathrm{O}, \mathrm{SO})$ on the allergenicity of Betula pendula, Ostrya carpinifolia, and Carpinus betulus pollen. Int J Environ Health Res 2014;1-10. 